\title{
Financial Feasibility of the Biogas Plant Installation in Terai Regions of Nepal
}

\author{
Shailendra Dhakal, , , Thakur Bhattarai ${ }^{2}$, Shiva Chandra Dhakal ${ }^{3}$ \\ ${ }^{1}$ Department of Agricultural Economics, Institute of Agriculture and Animal Science (IAAS), Tribhuvan University, Rampur Chitwan, Nepal \\ ${ }^{2}$ The Institute of Future Farming Systems, School of Medical and Applied Sciences, Central Queensland University, North Rockhampton, \\ Australia \\ ${ }^{3}$ Department of Agricultural Economics and Agribusiness Management, Agriculture and Forestry University, Rampur Chitwan, Nepal
}

Email address:

shailendra.dhakals@gmail.com (S. Dhakal)

${ }^{*}$ Corresponding author

To cite this article:

Shailendra Dhakal, Thakur Bhattarai, Shiva Chandra Dhakal. Financial Feasibility of the Biogas Plant Installation in Terai Regions of Nepal. International Journal of Economics, Finance and Management Sciences. Vol. 4, No. 3, 2016, pp. 153-156. doi: 10.11648/j.ijefm.20160403.18

Received: November 15, 2014; Accepted: May 11, 2016; Published: May 28, 2016

\begin{abstract}
Biogas plant has been seen as one of the most popular and environmentally friendly strategies for tackling with climate change and improving livelihood of people in developing countries. However, the financial feasibility of establishing in the rural and low income communities is the major issue. A survey research was conducted to study the feasibility of biogas plant installation in Chitwan district of Nepal. Altogether 120 households, 60 from Gitanagar and 60 from Patihani were selected using the simple random sampling technique comprising 30 adopters and 30 non adopters of biogas from each VDC. The primary information was collected from face to face semi structured interview schedule. The secondary data related to the climatic pattern, trends were obtained from different publication and journals. The study related to the economic feasibility of the biogas revealed that the biogas was an alternative household energy source in the study area which had significant impact on the reduction of mosquito breeding, flies and rodents, foul odor, and smoke. The amount of the firewood consumption had drastically decreased from about the 2 quintal to $60 \mathrm{~kg}$ per month. The result from the Benefit-Cost Ratio was 1.62 at $14 \%$ rate of discount. The NPV was found to be Rs. 128113.10; IRR was 54.67\%, Pay Back Period of 3 years signifying that the installation of the biogas was economically viable. Hence, the biogas may have multiple functions in the mitigation, adaptation as well as environmental and economic empowerment of the vulnerable section of the population in the country.
\end{abstract}

Keywords: Climate Change, Feasibility, Biogas, Benefit-Cost Ratio, Vulnerable, Mitigation, Adaptation, Nepal

\section{Introduction}

Climate change is the most perilous global challenge to the present world. The impacts of climate change on societies around the world are increasingly evident. Nepal is one of the most vulnerable countries to climate change whose economic sectors and livelihoods are experiencing the manifestations of the problem (World Bank, 2003).

Least developed and developing countries are more vulnerable to the climate change induced impacts and they face the great difficulties due to the lack of proper adaptation efforts (Orindi and Eriksen, 2005). However, biogas can be the effective means to adapt to the harsh conditions, which is not used extensively by livestock holder. The economics of biogas use and eco-friendly approach are not easily accepted by farming groups.

The reports published (UNDP, 2010 and Regmi et al., 2008) argues that women and men are differently impacted by climate change/variability, depending on their roles and responsibilities and decision making structure in the households to community. Men and women will be differently impacted and vulnerable to climate change because of the existing inequalities such as unequal access to resources, gendered divisions of labor and decision-making power that may affect the ability to respond to the effects of climate change (Medany et al., 2007). The gender relates to 
energy and poverty as women and girls are generally responsible for kitchen activities in households and they spent their time in gathering fuel, producing and processing food limiting their engagement in income generating activities and education and are often vulnerable to sexual harassment and assault as well as to injuries from carrying heavy loads long distances (UNDP, 2010).

Enhanced energy security and climate change mitigation are the main drivers for the transformation of the energy system from fossil to renewable sources. Biomass has to play a key role in this transformation to a low carbon economy. The energy consumption of Nepalese people is very low (402 GJ per year for the entire country, which is equivalent to 9.3 million liters of oil) (Water and Energy Commission Secretariat, 2010). The electricity grid supplies some of this energy. Fossil fuels are not available everywhere; they are contaminators and becoming more and more expensive. Although scarce, fuel wood constitutes $77.7 \%$ of the total energy consumption (WECS, 2010) and its use is devastating the forests. Smoke produced by the burning of fuel wood makes people ill. The solution is the development of cleaner, green energies. Biogas does not use and destroy the country resources, particularly forests; it transforms the problem of inadequate sanitation into energy. It is a 'closing the loop' answer. Replacing firewood with biogas would have a positive effect on deforestation and would improve the local environments, ecosystems, problems with erosion and mitigate GHG (Bajgain, Shakya, 2005. According to Bishwas et al 2005, the biogas plays significant role in the reduction of the methane, which is 21 times aggressive GHG than $\mathrm{CO}_{2}$. According to BSP (2012), 260,889 households distributed across the 75 districts of Nepal have installed biogas plant which have reduced work load of mainly women and girls by about 3 hours/day/household. This research investigates the cost and benefits of establishing biogas plant, particularly in the Terai region of Central Nepal.

\section{Methodology}

The study was conducted in Chitwan district, the central region of inner Terai of Nepal. It was purposively selected for the study. The study focused on the adoption of the biogas in peri-urban area to cope with vulnerable climate change for raising livestock and farming purpose in two VDCs namely, Gitanagar and Patihani purposively; as they are marked as vulnerable to climate change (Dhakal, 2012). From each VDCs 60 households comprising 30 adopters and 30 non adopters of biogas were selected.

Both qualitative and quantitative research techniques were applied in this study, including observation, focus group discussion, key informant interviews and questionnaire survey. Secondary information were collected from the various published and unpublished sources like journals, research articles, proceedings of various NGOs and INGOs, reports of District Agriculture Development Office (DADO), District Development Committee (DDC), National Agriculture Research Council (NARC), District Livestock
Service Office (DLSO), Central Bureau of Statistics (CBS), Chitwan National Park, Village Development Committee (VDC), Community Development Organizations (CDOs), Biogas Provider, Biogas Support Program etc.

Data entry and analysis were done by using computer software package: Statistical Package for Social Science (IBM SPSS Statistics 20 version), STATA 12 and Microsoft Excel. The local units of measurements were corrected in to scientific one. Both descriptive and analytical methods were used to analyze the data.

The cost and the benefits associated with the biogas plant were quantified and estimated on the basis of the valuation of the time saved, fuel used, and chemical fertilizer. The economic analyses were based on the following assumptions:

- $6 \mathrm{~kg}$ of dung is required per $\mathrm{m}^{3}$ size of biogas plant

- $0.036 \mathrm{~m}^{3}$ of gas is produced per $\mathrm{kg}$ of fresh cattle dung

- $1 \mathrm{~m}^{3}$ of gas is equivalent to $3.5 \mathrm{~kg}$ of firewood

- The cost of firewood is Rs $9.00 / \mathrm{kg}$

The valuation of the slurry, firewood, time saved from the biogas use were calculated using the various approaches. The economic tools like Benefit Cost ratio, Pay Back Period (PBP), Net Present Value (NPV) and Internal Rate of Return (IRR) were employed for the economic analysis of the biogas plant installation and operation.

\subsection{B/C Ratio}

The benefit - cost ratio (BCR) is derived from the information compiled when calculating NPV. The BCR is the ratio of benefits per unit of cost (both in PV terms). The BCR is a numerical value, not usually displayed in currency terms. The formula is simply:

$$
\mathrm{B} / \mathrm{C} \text { Ratio }=\frac{\mathrm{Bt} /(1+\mathrm{r}) \mathrm{t}}{\mathrm{Ct} /(1+\mathrm{r}) \mathrm{t}}
$$

\subsection{Net Present Value}

Net present value (NPV) is a way of comparing the value of money now with the value of money in the future. It refers to the sum of the present values for each year's net cash flow less the initial cost of investment. A negative NPV should be rejected while a zero NPV makes the investor indifferent, in which case other factors and benefits relating to the investments should be considered. It is simply the present worth or value of the incremental net benefit or incremental cash flow stream. Mathematically, it can be calculated as:

$$
\mathrm{NPV}=\sum_{n=1}^{n} \frac{\mathrm{Bt}-\mathrm{Ct}}{(1+\mathrm{r})^{n}}
$$

Where,

$\mathrm{Bt}=$ Benefit stream at period ' $\mathrm{n}$ '

$\mathrm{Ct}=$ Cost stream at period ' $\mathrm{n}$ '

$\mathrm{r}=$ Discount rate

$\mathrm{n}=$ Number of years

Where $r$ is the discount rate, and $n$ is the expected lifetime of the fixed-dome biogas plant; $n=(1,2 \ldots 20)$. 


\subsection{Internal Rate of Return}

Internal Rate of Return (IRR) is a financial analysis tool that estimates the interest rate that would make the present value of a stream of net cash flows equal to zero. It was calculated as:

$\mathrm{IRR}=\mathrm{LDR}+\mathrm{D}\left[\mathrm{NPV}\right.$ at $\mathrm{LDR} / \sum \mathrm{NPV}$ at TDR $(-$ sign ignored $)$

Where, IRR $=$ Internal Rate of Return

$\mathrm{LDR}=$ Lower Discount Rate

$\mathrm{D}=$ Difference

$\sum=$ Summation

TDR $=$ Two Discount Rates

Where IRR is the discount rate. IRR higher than the discount rate means the investment is profitable.

\subsection{Sensitivity Analysis of Selected Economic Parameters}

Sensitivity analysis using estimated economic values (costs and benefits) from the family- sized biogas digesters was undertaken. There are many assumptions and uncertainties involved in the cost benefit analysis. The parameters may vary due to location (such as the price of fuel wood, interest rates), technology development (such as the change of lifetime biogas plants, improvement of cooking stove efficiency) and other factors.

\subsection{Payback Period}

It is defined as the time period required to recover the initial investment.

$\mathrm{PBP}=$ Initial investment (Rs.)/ Annual return (Rs.)

The economic evaluation of the biogas is done using the following framework.

\section{Result and Discussion}

The study revealed that the use of biogas had significant reduction in the time for firewood collection, mosquito breeding, flies and rodents, foul odor, and smoke in overall. As per the response of the household, the findings showed that the monthly mean firewood use was 7.30 bundles before and 2.81 bundles after. The least quantity of the firewood use was three bundles in a month before and no use at all after biogas installation. The maximum amount of the firewood use was 20 bundles before and 6 bundles after by the household. As the t-statistics showed, the firewood consumption decreased after biogas plant installation at $1 \%$ level of significance.

Table 1. Statistics about firewood use.

\begin{tabular}{lll}
\hline Statistics & Before & After \\
\hline Mean & 7.30 & 2.81 \\
Minimum & 3.00 & 0.00 \\
Maximum & 20.00 & 6.00 \\
Mean difference & $-4.49^{* * *}$ & \\
\hline
\end{tabular}

Source: Field survey, 2013
The findings showed that the mean sufficiency of one LPG cylinder was for 2.31 months before and 5.82 month after. The least duration of the LPG use was 1 month before and 3 months after biogas installation. The maximum duration of the LPG use was for 3 months before and 7 months after using the biogas by the household. As the t-statistics showed, the duration of one LPG increased after biogas plant installation at $1 \%$ level of significance.

Table 2. Statistics about the sufficiency of one cylinder of LPG (in month).

\begin{tabular}{lll}
\hline Statistics & Before & After \\
\hline Mean & 2.31 & 5.80 \\
Minimum & 1.00 & 3.00 \\
Maximum & 3.00 & 7.00 \\
Mean difference & $3.49 * * *$ & \\
\hline
\end{tabular}

Source: Field survey, 2013

The study revealed that the mean time spent for firewood collection was 2.2 and 0.33 hour before and after respectively. Maximum 4 hours were spent by the household for the collection of the firewood before and 1 hour after. It was found that the time spent for firewood collection decreased from 132 hours to only 20 hours for sixty households on an aggregate. The t-statistics showed that the use of biogas has significant role in the reduction of time for collecting the firewood by the household. The level of significance was at $1 \%$ with mean difference of 1.87 hours.

Table 3. Statistics about the time spent for firewood collection in a day (in hour).

\begin{tabular}{lll}
\hline Statistics & Before & After \\
\hline Mean & 2.20 & 0.33 \\
Minimum & 1.00 & 0.00 \\
Maximum & 4.00 & 1.00 \\
Mean difference & $-1.87^{* * *}$ & \\
\hline
\end{tabular}

Source: Field survey, 2013

The initial investment to be made for the construction of six cubic meter size was Rs. 57000. Assuming the discount rate 14\% (AEPC, 2013), the total discounted cash inflow and out flow were calculated. The payback period was calculated using the formula mentioned in the methodology.

From the financial analysis, analysis it was found that the Benefit cost ratio was found to be 1.62 at $14 \%$ rate of discount. This means that the investment in the biogas by Re 1 would provide return of 62 paisa. Therefore, the use of biogas plant is more viable as cost associated with it is outweighed by the benefit obtained.

The Net Present Value (NPV) was found to be Rs. 128113.10 which suggests that the construction of the biogas plant is economically viable. The payback period was found to be 2 years and 9 months. It means that the initial capital investment made is recovered by annual outcome with 2.75 years. The internal rate of return is more than $54.67 \%$, which is greater than the interest rate of bank. The sensitivity analysis also indicated that under the various changed parameter of biogas, the installation is economically viable. Therefore, it is worth considering that investment in the 
biogas plant construction by a household is rational and the economic return is higher than depositing in bank.

Table 4. Summary of the economic analysis of biogas plant installation.

\begin{tabular}{lll}
\hline Particulars & Unit & Value \\
\hline B/C Ratio & - & 1.62 \\
NPV & Rs. & 128113.10 \\
IRR & $\%$ & 54.67 \\
Payback Period & Yrs. & 2.75 \\
\hline
\end{tabular}

Source: Field survey, 2013

The above finding suggest that the installation of biogas in economically viable.

Impact of biogas slurry in chemical fertilizer use

The application of bio slurry had impact in the chemical fertilizer use in the field. According to respondent, the use of fertilizer was increasing before bio slurry use (33.00\%) whereas the increasing trend fell to 6.7 percent. However, the general trend show that the chemical fertilizer use decreased over time after bio slurry application. However, the interesting response from respondent was that there was no any change in application of chemical fertilizer although bio slurry was used (about 66\%). The organic content of the digested slurry improves the soil's texture, stabilizes its humic content, intensifies its rate of nutrient-depot formation and increases its water holding capacity (Uli Werner et al., 1989).

Table 5. Impact of the bio slurry in the use of chemical fertilizers.

\begin{tabular}{ll}
\hline Amount & After \\
\hline Increased & $4(6.70)$ \\
Decreased & $15(25.00)$ \\
Same & $41(68.30)$ \\
\hline
\end{tabular}

Figures in parenthesis indicate the percentage

\section{Conclusion}

The benefits of the biogas were remarkable which decreased the workload pressure in women, maintained the soil environment and the productivity, and maintained good health of the livestock and the households. The installation of the biogas is financially viable and the rational decision of any households that reduces the vulnerability due to climate change. The end user group viz. farmers should be provided the information about the benefits of the biogas and the various appropriate policy, schemes, subsidy, loan, for installation and post installation maintenance of biogas should be provided by the distributors and government to reduce the GHGs from household level.

\section{References}

[1] Bajgain, S. and I. Shakya. 2005. The Nepal Biogas Support Program: A successful model of public private partnership for rural household Bangladesh Village. Energy 22: 763-770.

[2] Bishwas, W. K. and D. J. N. Lucas. 1996. Economic Viability of Biogas Technology in a Bangladesh Village. Energy 22: 763-770.

[3] BSP Nepal (2012). Implementation Document, SNV/N. China. Renewable Energy 30: 99-108.

[4] Medany M, Niang-Diop I, Nyong T, Tabo R, Vogel C (2006). Background paper on impacts, vulnerability and adaptation to climate change in Africa. For the African Workshop on Adaptation Implementation of Decision organized by UNFCCC Convention Accra, Ghana, 21 - 23 September 2006.

[5] Orindi VA, Eriksen S (2005). "Mainstreaming adaptation to climate change in the development process in Uganda". Available at: http://www.acts.or.ke/pubs/monographs/pubs/ecopolicy 15.pdf (Retrieved on $10^{\text {th }}$ July, 2013).

[6] Regmi B, Adhikari A (2008). Country Case Study-Nepal: Local Initiatives for Biodiversity, Research and Development (LI-BIRD) in Human Development 2007/2008 Report: Fighting Climate Change: Human Solidarity in a Divided World, UNDP.

[7] Uli Werner et al. 1989. Biogas plants in animal husbandry: a practical guide; a publication of Deutsches Zentrum für Entwicklungstechnologien - GATE in Deutsche Gesellschaft für Technische Zusammenarbeit (GTZ).

[8] UNDP (2010). Gender, climate change and community-based adaptation.

[9] WECS (2010). Alternate Energy Technology: An Overview and Assessment. Perspective Energy Plan, Supporting Document No.3. Report No. 2/1/010595/2/9 Seq. No. 468.

[10] World Bank (2003). World development report 2003: sustainable development in a dynamic world. New York, Oxford University Press. pp. 24-29. 